\title{
Drought stress response in Jatropha curcas: Growth and physiology
}

\author{
Helena Sapeta $^{\mathrm{a}}$, J. Miguel Costa ${ }^{\mathrm{b}, \mathrm{c}}$, Tiago Lourenço ${ }^{\mathrm{a}}$, João Maroco ${ }^{\mathrm{d}}$, Piet van der Linde ${ }^{\mathrm{e}}$, \\ M. Margarida Oliveira ${ }^{\mathrm{a}, *}$
}

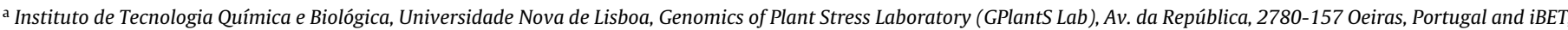 \\ Apartado 12, 2781-901 Oeiras, Portugal

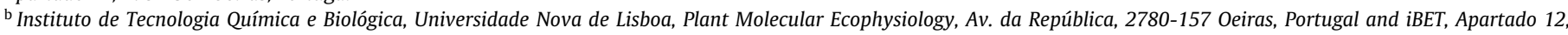 \\ 2781-901 Oeiras, Portugal \\ c Centro de Botânica Aplicada à Agricultura, Instituto Superior de Agronomia-UTL, Tapada da Ajuda,1349-017 Lisboa, Portugal \\ d Grupo de Estatística e Matemática, ISPA-Instituto Universitário, Rua Jardim do Tabaco, 34, 1149 - 041 Lisbon, Portugal \\ e QUINVITA NV, Derbystraat 71, B-9051 Ghent, Belgium
}

\section{A R T I C L E I N F O}

\section{Article history:}

Received 21 May 2012

Received in revised form 14 August 2012

Accepted 28 August 2012

\section{Keywords:}

Purging nut

Drought stress

Re-watering

Leaf morphology

Leaf gas exchange

Photochemistry

\begin{abstract}
A B S T R A C T
Tolerance to drought remains poorly described for Jatropha curcas accessions from different geographical and climatic origins. To address this issue we studied the response of two J. curcas accessions, one from Indonesia (wet tropical climate) and the other from Cape Verde islands (semi-arid climate). Potted seedlings (with 71 days) of both accessions were subjected to continuous well watered conditions (control) or to a drought stress period followed by re-watering. To mimic natural conditions in which drought stress develops gradually, stress was imposed progressively by reducing irrigation (10\% reduction every 2 days, on a weight base), for a period of 28 days, until a field capacity of $15 \%$ (maximum stress) was achieved, followed by one week under well-watered conditions. We measured soil and plant water status, growth and biomass partitioning, leaf morphology, leaf gas exchange and chlorophyll $a$ fluorescence. Both accessions maintained high leaf relative water content (70-80\%) even at maximum stress. Net photosynthesis $\left(A_{n}\right)$ was not affected by mild to moderate stress but it abruptly dropped at severe stress. This was due to reduced stomatal conductance, which showed earlier decline than $A_{n}$. Plant growth (stem elongation, leaf emergence and total leaf area) was reduced, minimizing water loss, but no significant differences were found between accessions. Drought stress did not reduce chlorophyll contents but led to reduced chlorophyll $a / b$. Both accessions showed fast recovery of both stomatal and photochemical parameters suggesting a good tolerance to water stress. Both J. curcas accessions showed a-dehydrationavoidant behaviour, presenting a typical water saving strategy due to strict stomatal regulation, regardless of their provenance.
\end{abstract}

(c) 2012 Elsevier B.V. All rights reserved.

\section{Introduction}

Crop losses resulting from abiotic stresses such as drought or salinity can reduce crop yield by as much as 50\% (Boyer, 1982; Chaves and Oliveira, 2004). Climate changes are expected to exacerbate this situation due to the increasing incidence of more extreme climate events. In this context, plants with improved performance

Abbreviations: $A_{n}$, net photosynthesis; $\mathrm{C}$, control conditions; $C_{i}$, internal $\mathrm{CO}_{2}$ concentration; CVi, Cape Verde islands accession; DW, dry weight; $\mathrm{E}$, transpiration rate; ETR, electron transport rate; FC, field capacity; $g_{s}$, stomatal conductance to water vapour; Ind, Indonesia accession; PPFD, photosynthetic photon flux density; $\mathrm{R}$, re-watering period; RWC, relative water content; $S$, drought stress conditions; $\mathrm{S}: \mathrm{R}$, shoot to root dry mass ratio; SLA, specific leaf area; SWA, soil water availability; TLA, total leaf area; WUE $E_{\mathrm{i}}$, intrinsic water use efficiency $\left(A_{n} / g_{s}\right) ; \Phi_{\mathrm{PSII}}$, photosystem II operating efficiency.

* Corresponding author. Tel.: +351 214469647; fax: +351214411277.

E-mail address: mmolive@itqb.unl.pt (M.M. Oliveira). under sub-optimal environmental conditions, or with increased tolerance to severe abiotic stress, are potential sources of genes for breeding of agricultural and forestry crops.

Jatropha curcas (purging nut) is a soft-woody oil-seed bearing plant of the Euphorbiaceae family that has emerged as a potential source of biodiesel (Fairless, 2007). The species has been described as drought tolerant and capable of growing in marginal and poor soils (Heller, 1996; Fairless, 2007; Divakara et al., 2010). J. curcas has potential to be cultivated under semi-arid and poor soil conditions without competing with food production for land use (Fairless, 2007; Divakara et al., 2010).

Outside Meso-America, its centre of origin, J. curcas has low genetic diversity (Kumar et al., 2008a,b; Pamidimarri et al., 2008a, 2008b; Popluechai et al., 2009). However, phenotypic variations are described for physiological and biochemical traits (Heller, 1996; Ginwal et al., 2004; Kaushik et al., 2007; Rao et al., 2008; Popluechai et al., 2009). Recent studies also suggest that phenotype variation is epigenetically controlled (Popluechai et al., 2009; Yi et al., 2010; 
Kanchanaketu et al., 2012). However, little is known about physiological traits and the adaptation capacity of J. curcas to changing and more adverse climate conditions. These knowledge gaps restrict our capacity to properly evaluate and predict the agronomic performance of $J$. curcas in response to extreme environments, especially in terms of growth (biomass) and seed yield traits. Until now, selection of J. curcas genotypes has focused on oil traits instead of on physiological traits, such as carbon and water use efficiency or water stress response. This is particularly surprising if we consider that the major cultivation areas of $J$. curcas are often characterized by frequent soil water deficit and excessive salinity (Fairless, 2007; Divakara et al., 2010). Therefore, improved knowledge on J. curcas physiology is needed to support breeding programs, selecting superior genotypes and optimization of crop management.

In different crops, physiological responses to drought vary with the genotype (Anyia and Herzog, 2004; Bacelar et al., 2007; Centritto et al., 2009; Costa et al., 2012). The study of stress/recovery responses contributes to a better understanding of the plant's ability to adapt to different environments and climatic conditions. The recovery is an important component of plant's response, and in the particular case of drought, carbon balance depends not only on the rate and degree of photosynthetic decline under water depletion, but also on the capacity for photosynthetic recovery after water supply (Chaves et al., 2003; Flexas et al., 2004, 2007; Miyashita et al., 2005).

The ability of $J$. curcas to grow in marginal and dry soils has been poorly explored. Several studies have been published describing plant performance (biomass production and partitioning, plant-water relationships, leaf gas exchange and osmotic adjustment) under conditions of limited water availability (Maes et al., 2009; Achten et al., 2010; Pompelli et al., 2010; Silva et al., 2010a,b; Díaz-López et al., 2012). Two studies have compared the behaviour of accessions from different provenances (Maes et al., 2009; Achten et al., 2010).

In order to better understand the putative impact of the geographic origin on plant responses to water stress, we followed the drought/re-watering response of two J. curcas accessions with distinct geographical and climatic provenances (Cape Verde islands-arid climate, versus Indonesia - wet tropical climate) under semi-controlled conditions. Growth and morpho-physiological responses of the two accessions along drought stress and rewatering are described with focus on growth morphology and photosynthetic and stomatal responses.

\section{Material and methods}

\subsection{Plant material and growing conditions}

We tested two accessions of $J$. curcas from two distinct climate regions, one from a wet tropical region and the other from an arid climate. The first accession was originary from Indonesia (Ind, GPS coord: S3 ${ }^{\circ} 14^{\prime} 28.82^{\prime \prime}$, E102 ${ }^{\circ} 57^{\prime} 44.95^{\prime \prime}$ ) while the second one was from Cape Verde islands (CVi, GPS coord: N14 ${ }^{\circ} 7^{\prime}$ $\left.16.11^{\prime \prime}, \mathrm{W} 23^{\circ} 36^{\prime} 19.68^{\prime \prime}\right)$. Seeds from both accessions were used in Cape Verde islands to produce the mother plants from which we obtained the seeds used in this work. Seeds were germinated in clean sand, and 10-day-old homogeneous seedlings were transplanted to $7.5 \mathrm{~L}$ pots containing a soil mixture of sand, peat and soil (3:1:1) and supplemented with a commercial fertilizer (Osmocote, Scotts, Netherlands) (10.5 g/pot) (N:P:K:Mg, 16:9:12:2.5). Plants were grown in a climatic chamber with daily irrigation until the beginning of the treatments. Experiments were carried out in a growth chamber $(3 \mathrm{~m} \times 6 \mathrm{~m} \times 2.8 \mathrm{~m})$ with a day/night temperature of $28 \pm 2{ }^{\circ} \mathrm{C} / 20 \pm 4{ }^{\circ} \mathrm{C}$, and day/night relative humidity of $35 \pm 5 \% / 75 \pm 5 \%$. A photoperiod of $12 \mathrm{~h}$ was used, with a light intensity at plant level of $172 \pm 66 \mu \mathrm{mol}$ photons $\mathrm{m}^{-2} \mathrm{~s}^{-1}$, provided by a mixture of high-pressure sodium (SON/T-Agro $400 \mathrm{~W}$, Philips, Belgium) and metal-halide (Master HPI/T Plus $400 \mathrm{~W}$, Philips, Belgium) lamps. Pots were randomly moved every week to minimize position effects.

\subsection{Treatments}

Potted 71-day-old plants of the two accessions were subjected to drought stress $(\mathrm{S})$ or continuously grown under well-watered conditions (C, control). Drought stress was imposed by subjecting plants to a gradual decrease of soil water availability ( $10 \%$ reduction every 2 days on a weight base) for a maximum period of 28 days $(\mathrm{S})$, followed by a 7-day re-watering period (R).

\subsection{Parameters}

\subsubsection{Soil and plant water status}

Soil water availability (SWA) was calculated as $\mathrm{SWA}=[($ Pot weight - Minimum Pot Weight $) /($ Maximum Pot Weight - Minimum Pot Weight $)] \times 100$. Minimum pot weight was considered to be pot's weight containing a totally dry soil mixture. For this measurement soil was spread in a fine layer and air-dried in the glasshouse until a constant weight was achieved. Maximum pot weight was measured when soil was at field capacity (FC).

Leaf relative water content (RWC) was determined at maximum stress (day 28) and at the end of the experiment (day 35). For this purpose, six leaf discs $(\varnothing=19 \mathrm{~mm})$ were collected for each plant from the three youngest expanded leaves (2 discs per leaf). Five plants were analysed per treatment. RWC was calculated according to Barrs and Weatherly (1962) using the formula: RWC $(\%)=[(\mathrm{FW}-\mathrm{DW}) /(\mathrm{TW}-\mathrm{DW})] \times 100$, where FW, DW and TW are fresh, dry and turgid weight, respectively.

\subsubsection{Growth and morphology}

Stem growth characteristics were weekly monitored by measuring length (from substrate surface to the apical meristem) and diameter (at the base) and by counting the number of leaves longer than $2 \mathrm{~cm}$. The relative increase in stem length, stem diameter and number of leaves was calculated. Fresh weight of leaves, roots and shoots was determined at the end of the experiment (day 35). Dry weight (g) was determined after drying plant material at $70^{\circ} \mathrm{C}$ (until a constant weight was achieved). Shoot to root dry mass ratio $(S: R)$ was calculated. The specific leaf area (SLA) was calculated as leaf area per unit dry mass $\left(\mathrm{cm}^{2} \mathrm{~g}^{-1}\right)$. Total leaf area (TLA) was determined with a colour image analysis system (WinDIAS 2, Delta-T Devices, Cambridge, UK).

\subsubsection{Leaf gas exchange, Chl fluorescence and Chl content}

Leaf gas exchange was assessed with a portable infrared gas analyzer (LI-6400; LI-COR Inc., Lincoln, USA) equipped with a fluorometer (LI-6400-40, LI-COR Inc., Lincoln, USA). Before the experiments, light response curves were performed $5-11 \mathrm{~h}$ after photoperiod initiation, using fully expanded leaves of 71 days-old plants under good illumination. We used a block temperature of $28^{\circ} \mathrm{C}$, with $\mathrm{CO}_{2}$ concentration at $400 \mathrm{ppm}$ and an air flow rate of $500 \mu \mathrm{mol} \mathrm{s}^{-1}$. Photosynthetic photon flux density (PPFD) was gradually decreased from 2000 to 0 ( $2000 ; 1750 ; 1500 ; 1200 ; 900 ; 700$; $500 ; 250 ; 100 ; 70 ; 50$ and $0 \mu \mathrm{mol}$ photon $\mathrm{m}^{-2} \mathrm{~s}^{-1}$ ) in order to avoid limitation of photosynthesis at high light due to insufficient stomatal opening, caused by the initial lower light intensities (Singsaas et al., 2001). A 2-3 min acclimation period was performed between the measurements of the 12 light levels.

Along the experiments, we monitored net photosynthesis $\left(A_{n}, \mu \mathrm{mol} \mathrm{CO}_{2} \mathrm{~m}^{-2} \mathrm{~s}^{-1}\right)$, transpiration (E, mol $\mathrm{H}_{2} \mathrm{O} \mathrm{m}^{-2} \mathrm{~s}^{-1}$ ), stomatal conductance to water vapour $\left(g_{s}, \mathrm{~mol} \mathrm{H}_{2} \mathrm{O} \mathrm{m}^{-2} \mathrm{~s}^{-1}\right)$ 


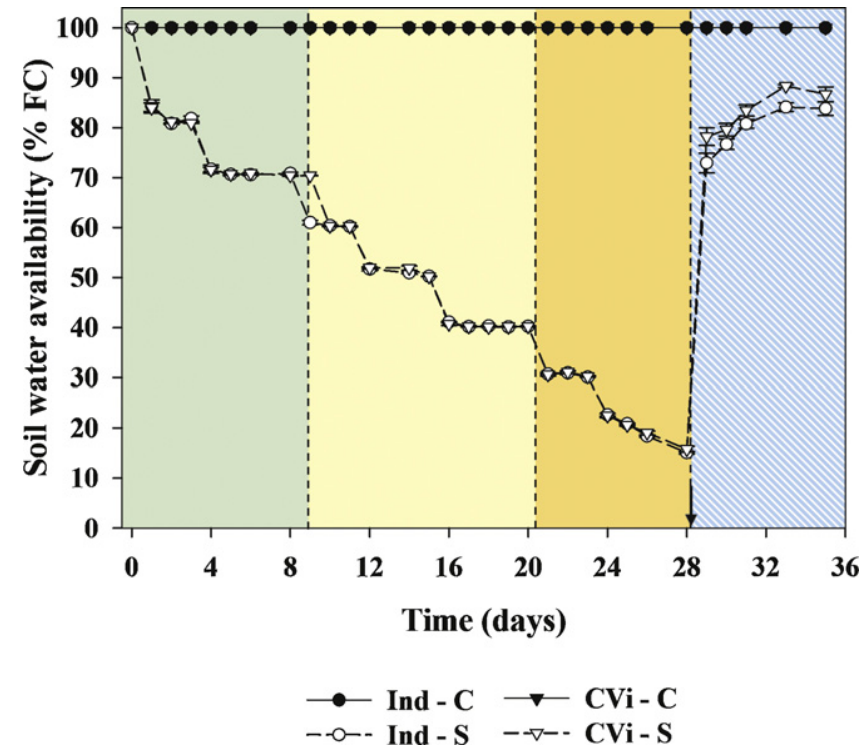

Fig. 1. Soil water availability along the experiment for two Jatropha curcas accessions from Indonesia (Ind) and Cape Verde islands (CVi), continuously grown under well-watered control conditions (C) or subjected to drought stress (S) for 28 days followed by a 7-day re-watering period. Background colour indicates: non to mild stress (100-70\% FC) (grey); mild to moderate stress (70-30\% FC) (light grey); severe stress (30-15\% FC) (dark grey); no stress (dashed). The arrow at day 28 indicates re-watering start. Values are means. Bars represent $\pm \operatorname{SE}(n=5)$.

and internal $\mathrm{CO}_{2}$ concentration $\left(C_{i}\right.$, ppm). Data was periodically collected from the youngest fully expanded leaf $(5-9 \mathrm{~h}$ after photoperiod initiation), never extending a total period of $90 \mathrm{~min}$. Block temperature was set at $28^{\circ} \mathrm{C}$, light intensity was set at $300 \mu \mathrm{mol}$ photons $\mathrm{m}^{-2} \mathrm{~s}^{-1}$ (based on the light curves responses Fig. 3) and $\mathrm{CO}_{2}$ concentration was kept at $400 \mathrm{ppm}$ with an air flow rate of $500 \mu \mathrm{mol} \mathrm{s}^{-1}$. Intrinsic water use efficiency $\left(\mathrm{WUE}_{\mathrm{i}}=A_{n} / g_{s}, \mu \mathrm{mol} \mathrm{CO} \mathrm{mol}^{-1} \mathrm{H}_{2} \mathrm{O}\right.$ ) and instantaneous carboxylation efficiency $\left(A_{n} / C_{i}, \mu \mathrm{mol} \mathrm{CO}_{2} \mathrm{~m}^{-2} \mathrm{~s}^{-1} \mathrm{ppm}^{-1}\right)$ were calculated as well. By simultaneously measuring $\mathrm{Chl}_{a}$ fluorescence we could also evaluate the photosystem II operating efficiency ( $\Phi_{\text {PSII }}$ ), which translates photochemistry efficiency (Genty et al., 1989; Maxwell and Johnson, 2000). PSII operating efficiency was calculated as (Fm'-Fs)/F'm (Genty et al., 1989). Fs and Fm' represent the steady state and maximum fluorescence measured under light adapted conditions. We estimated the electron transport rate $\left(\mathrm{ETR}=\Phi_{\mathrm{PSII}} \times \mathrm{PPFD} \times 0.5 \times 0.84, \mu \mathrm{mol}\right.$ electron $\left.\mathrm{m}^{-2} \mathrm{~s}^{-1}\right)($ Bjökman and Demmig, 1987), where the PPFD is the photon flux density of photosynthetically active radiation $(400-700 \mathrm{~nm}), 0.84$ is the assumed light absorbance of the sample, and 0.5 is the fraction of excitation energy diverted to the photosystem II. The contents $\left(\mathrm{mg} \mathrm{g}^{-1} \mathrm{DW}\right)$ of chlorophyll $a\left(\mathrm{Chl}_{a}\right)$ and chlorophyll $b\left(\mathrm{Chl}_{b}\right)$ were determined according to Lichtenthaler (1987) at maximum stress (day 28) and at the end of the experiment (day 35). Three leaf discs $(\varnothing=19 \mathrm{~mm}$ ) were collected for each plant from the three youngest expanded leaves ( 1 disc per leaf). Five plants were analysed per treatment. Absorbance was measured with a spectrophotometer (DU-70 Spectrophotometer, Beckman, USA) at 663.2 and $646.8 \mathrm{~nm}$. $\mathrm{Chl}_{a / b}$ was also calculated.

\subsection{Statistics}

Data collected were subjected to Analysis of Variance (ANOVA) using the statistical software SPSS Statistics (v20, SPSS an IBM company, Chicago, USA). Mean comparison was carried out using Tukey's multiple comparison test using the statistical software

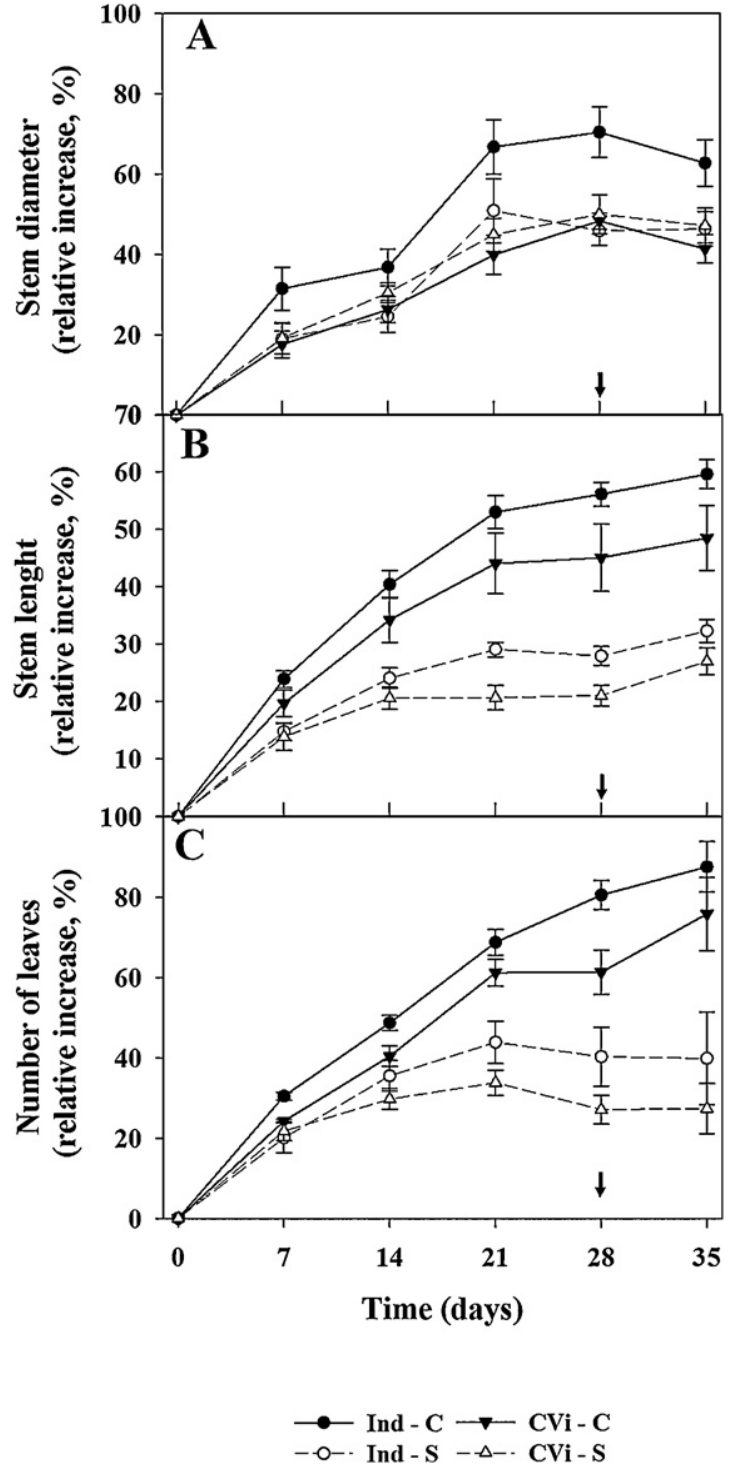

Fig. 2. Effect of drought stress and re-watering on (A) stem diameter,(B) stem length and $(C)$ leaf number (values represent the \% of increase, relative to day 0 ) measured for two accessions of Jatropha curcas from Indonesia (Ind) and Cape Verde islands $(\mathrm{CVi})$, continuously grown under well watered control conditions (C) or subjected to drought stress (S) for 28 days followed by a 7-day re-watering period. Arrows at day 28 indicate re-watering start. Values are means. Bars represent $\pm \operatorname{SE}(n=5)$.

package SIGMAPLOT 11.0 (Systat Software Inc., Chicago, USA). Significant results were assumed for $p \leq 0.05$.

\section{Results}

\subsection{Soil and plant water relations}

Soil water availability decreased $10 \%$ every 2 days along the imposed drought period reaching a minimum of $15 \%$ by day 28 (maximum stress) for both accessions (Fig. 1). Based on the observed decrease of SWA we have considered the existence of three major soil water deficit categories: (1) non to mild stress (100-70\% FC; day 0-9); (2) mild to moderate stress (70-30\% FC; day 10-20) and (3) severe stress (30-15\% FC, day 21-28). Regarding leaf RWC (Table 1), we found that CVi maintained a higher water content than Ind, in both control and maximum stress conditions. Both accessions at maximum stress showed higher RWC than the control. However, at the end of the re-watering period no differences 
Table 1

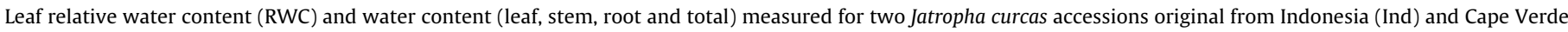

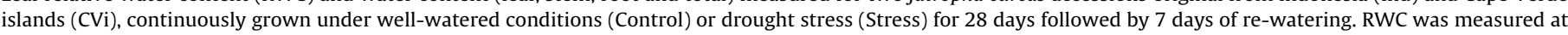

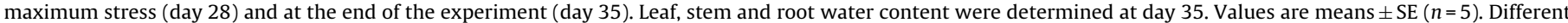
letters within the same column indicate significant differences according to the Tukey's test $(p<0.05)$.

\begin{tabular}{|c|c|c|c|c|c|c|c|}
\hline & & \multicolumn{2}{|l|}{ Leaf RWC (\%) } & \multicolumn{4}{|c|}{ Water content $\left(\% \mathrm{H}_{2} \mathrm{O}\right)$} \\
\hline & & Maximum stress & End of recovery & & End of recov & & \\
\hline \multirow{3}{*}{$\begin{array}{l}\text { Accession } \\
\text { Ind }\end{array}$} & & & & Leaf & Stem & Root & Total \\
\hline & Control & $66.4 \pm 0.6 b$ & $72.4 \pm 1.8 \mathrm{a}$ & $94.4 \pm 0.1 \mathrm{a}$ & $83.9 \pm 1.7 a$ & $85.1 \pm 0.3 \mathrm{ab}$ & $89.5 \pm 0.4 a$ \\
\hline & Stress & $73.5 \pm 2.6 a b$ & $71.9 \pm 3.6 a$ & $93.9 \pm 0.9 a$ & $85.9 \pm 0.7 a$ & $86.2 \pm 1.1 \mathrm{a}$ & $89.6 \pm 0.9 a$ \\
\hline \multirow[t]{3}{*}{ CVi } & Control & $75.6 \pm 2.5 \mathrm{ab}$ & $75.7 \pm 1.3 \mathrm{a}$ & $94.2 \pm 0.5 \mathrm{a}$ & $86.1 \pm 0.5 a$ & $85.8 \pm 0.3 a$ & $90.0 \pm 0.5 a$ \\
\hline & Stress & $82.9 \pm 3.3 a$ & $69.9 \pm 1.1 \mathrm{a}$ & $92.9 \pm 0.5 \mathrm{a}$ & $85.3 \pm 0.3 a$ & $83.1 \pm 0.6 b$ & $88.2 \pm 0.4 a$ \\
\hline & $p$-value & 0.002 & 0.348 & 0.296 & 0.393 & 0.020 & 0.194 \\
\hline
\end{tabular}

were observed between treatments or accessions ( $p=0.348)$. We found high levels of water content in leaves, stems and roots with values equal or above $80 \%$ (Table 1 ). Moreover, we found significant differences between accessions for root water content $(p=0.02)$. Roots from Ind plants had significantly higher water content than roots from CVi plants after the re-watering period (83.1 against $86.2 \%$, for CVi and Ind respectively).

\subsection{Growth and morphology}

The relative increase of stem diameter was not much affected by drought $(p=0.048)$ (Fig. 2A). Values were identical in both accessions and no differences were found until day 14 of the experiment $(p=0.122)$. From day 21 onwards, the Ind control plants presented larger stems $(p=0.036)$ compared to the other plants. Although from day 21 onwards stem diameter enlargement was arrested, for both stressed and non-stressed plants, at maximum stress (day 28 ) the arrest was more pronounced for the Ind stressed plants when compared with its control $(p=0.007)$. Drought arrested stem length and leaf number relative increase $(p<0.001)$ (Fig. 2B and C). A reduction was observed for the relative increase of stem length and leaf number from day 7 onwards $(p=0.008$ and $p=0.028$, respectively), with stem elongation and leaf emergence being arrested at severe stress (30-15\% SWA, days 21 to 28 ). Nevertheless, stem elongation was rapidly resumed after re-watering (Fig. 2B, day 28-35). Along the experimental period stem diameter varied between 1.2 and $1.8 \mathrm{~cm}$ and stem length varied between 36 and $50 \mathrm{~cm}$ (data not shown). The number of leaves varied between 13 and 20 (data not shown). No differences were observed between treatments at the end of the experiment for leaves $(p=0.150)$, stem $(p=0.356)$, roots $(p=0.516)$ or total biomass $(p=0.446)$ (Table 2$)$. Similarly no differences existed between accessions or treatments for $S: R$ $(p=0.221)$ (Table 2$)$. We found however, marginal differences for TLA $(p=0.054)$ and SLA $(p=0.068)$. Drought led to a reduction of TLA for both accessions. Moreover the CVi plants present higher leaf area both in control and drought conditions. Despite the high variation between SLA values, no specific trend was observed between provenances or imposed treatments.

\subsection{Leaf gas exchange, Chl fluorescence and Chl content}

Net photosynthesis response to increasing light was similar for both accessions (Fig. 3A). For both accessions $A_{n}$ increased rapidly as PPFD increased to $250 \mu \mathrm{mol}$ photon $\mathrm{m}^{-2} \mathrm{~s}^{-1}$ (the linear phase), slowly increasing thereafter to a maximum of $1200 \mu \mathrm{mol}$ photon $\mathrm{m}^{-2} \mathrm{~s}^{-1}$ (the light saturation point), and remaining constant during light intensity increase up to $2000 \mu \mathrm{mol}$ photon $\mathrm{m}^{-2} \mathrm{~s}^{-1}$ (Fig. 3A). The light compensation point was estimated to be approximately 1.6 and $1.2 \mu \mathrm{mol}$ photon $\mathrm{m}^{-2} \mathrm{~s}^{-1}$ (for the Ind and the CVi accessions, respectively). The internal $\mathrm{CO}_{2}$ rapidly decreased until an irradiance level of $250 \mu \mathrm{mol} \mathrm{m}^{-2} \mathrm{~s}^{-1}$ (Fig. 3B), slowly increasing afterwards until the maximum light level was reached $\left(2000 \mu \mathrm{mol} \mathrm{m}^{-2} \mathrm{~s}^{-1}\right)$. The $C_{i}$ response pattern was identical for both accessions, although from $1200 \mu \mathrm{mol} \mathrm{m}^{-2} \mathrm{~s}^{-1}$ the Ind accession presented slightly lower $C_{i}$ values.

Values and variation of net photosynthesis along the experiment were similar in both accessions (Fig. 4A). $A_{n}$ values under drought were similar to those observed for control plants until day 20 , declining thereafter. Both accessions presented a fast decrease of $A_{n}$ under severe water deficit (30-15\% of SWA, days 23-28), with a reduction of $77 \%$ and $78 \%$ in Ind and CVi plants respectively at maximum stress (SWA of 15\%) as compared to control $(p=0.009)$. Values of $A_{n}$ for control varied between 8 and $12 \mu \mathrm{mol} \mathrm{CO}_{2} \mathrm{~m}^{-2} \mathrm{~s}^{-1}$ in both accessions. Stomatal conductance to water vapour had a different pattern from $A_{n}$ as it showed an earlier decrease (Fig. 3A and B). Stomatal conductance was reduced by $42 \%$ (in Ind) and $33 \%$ (in CVi) at day 11 (SWA of 60\%) while at maximum stress (15\% SWA, reached by day 28 ), the reduction was of $96 \%$ and $99 \%$ respectively as compared to the control $(p<0.001)$. The pronounced decrease of $g_{s}$ and the maintenance of net photosynthesis, caused a strong reduction in $C_{i}$, from day 11 to 23 (60-30\% of SWA), with minimum values of about $180 \mathrm{ppm}$ (data not shown). An identical reduction pattern was observed for leaf transpiration (E) (data not shown).

Increased $W E_{i}$ for stressed plants was observed since day 11 (Fig. 4E). Instantaneous carboxylation efficiency $\left(A_{n} / C_{i}\right)$ also increased in both accessions until day 23 (Fig. 4F) but the marked reduction in $A_{n}$ at severe stress, decreased $A_{n} / C_{i}$ to values close to 0 by day 26 of the experiment. Concerning $\mathrm{Chl}_{a}$ fluorescence parameters, we observed an abrupt reduction of the PSII operating efficiency ( $\Phi_{\text {PSII }}$ ) since day 26 (20\% of SWA) until day 28 (maximum stress) (Fig. 4C). Identical behaviour was observed for ETR (Fig. 4D). Regarding recovery after re-watering, leaf gas exchange $\left(A_{n}, g_{s}\right)$ and photochemical ( $\Phi_{\text {PSII }}$ and ETR) parameters revealed a complete recovery within $24 \mathrm{~h}$ (day 29) (Fig. 4). WUE $\mathrm{E}_{\mathrm{i}}$ and instantaneous carboxylation efficiency (Fig. 3E and F) of water stressed plants also fully recovered to control values after 3 days of re-watering.

At maximum stress (day 28), a higher content of $\mathrm{Chl}_{a}$ and $\mathrm{Chl}_{b}$ appeared to occur in stressed plants, although this was not supported by statistical analysis. This tendency was especially evident for the Ind accession (Fig. 5A and B). Although the increase of $\mathrm{Chl}_{b}$ was not significant, it resulted in a significant reduction of the $\mathrm{Chl}_{a / b}$ $(p=0.005)$ (Fig. 5C). After the 7-day re-watering period we observed the full recovery of $\mathrm{Chl}_{a / b}$ values and no differences existed between stressed and control plants of both accessions.

\section{Discussion}

We have characterized $J$. curcas physiology and growth in response to water stress using seedlings of two accessions originating from contrasting climatic conditions. We found no, or only minor, effect of the accession on the morpho-physiological 
Table 2

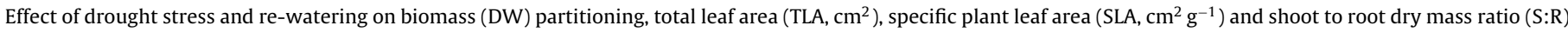

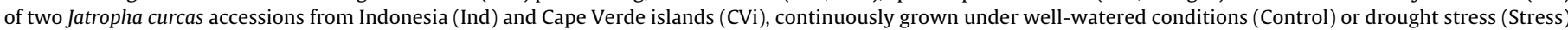

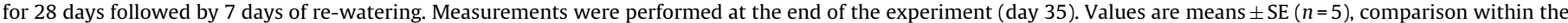
same column was performed with Tukey's test.

\begin{tabular}{|c|c|c|c|c|c|c|c|c|}
\hline \multirow[b]{2}{*}{ Accession } & & \multicolumn{4}{|c|}{ Biomass (g) } & \multirow[t]{2}{*}{$\operatorname{TLA}\left(\mathrm{cm}^{2}\right)$} & \multirow[t]{2}{*}{$\operatorname{SLA}\left(\mathrm{cm}^{2} \mathrm{~g}^{-1}\right)$} & \multirow[t]{2}{*}{$\mathrm{S}: \mathrm{R}$} \\
\hline & & Leaf & Stem & Root & Total & & & \\
\hline \multirow[t]{2}{*}{ Ind } & Control & $14.7 \pm 1.7$ & $10.6 \pm 1.6$ & $6.1 \pm 0.7$ & $31.4 \pm 4.0$ & $3510 \pm 349$ & $241.2 \pm 5.4$ & $2.7 \pm 0.1$ \\
\hline & Stress & $11.1 \pm 0.7$ & $9.6 \pm 1.3$ & $5.2 \pm 1.0$ & $25.9 \pm 2.8$ & $2808 \pm 99$ & $254.1 \pm 8.3$ & $3.0 \pm 0.2$ \\
\hline \multirow[t]{3}{*}{ CVi } & Control & $13.3 \pm 0.7$ & $9.4 \pm 0.6$ & $5.9 \pm 0.3$ & $28.7 \pm 1.7$ & $3645 \pm 202$ & $257.3 \pm 14.0$ & $2.6 \pm 0.1$ \\
\hline & Stress & $12.7 \pm 0.5$ & $12.2 \pm 1.1$ & $6.7 \pm 0.7$ & $31.6 \pm 2.1$ & $3129 \pm 101$ & $247.2 \pm 3.4$ & $2.9 \pm 0.1$ \\
\hline & $p$-value & 0.150 & 0.356 & 0.516 & 0.446 & 0.054 & 0.068 & 0.221 \\
\hline
\end{tabular}

responses to drought and on the recovery following re-watering. This agrees with previous studies for J. curcas where growth conditions appeared to have larger influence on plant performance in response to stress than the respective genetic background (Maes et al., 2009; Achten et al., 2010). In our experimental conditions net photosynthesis was only significantly reduced when SWA dropped below 30\%. Meanwhile, stomatal conductance to water vapour showed to be quite sensitive to soil water availability and a strict stomatal regulation in $J$. curcas was evident by reduced $g_{s}$ since day 11. The maintenance of $A_{n}$ values under moderate stress resulted in increased $W_{U E}$. This water conservation strategy can justify the maintenance of high leaf relative water contents even under severe stress (15\% of SWA). It is also possible that the osmotic adjustment capacity has contributed to maintain a high water content of tissues, as previously suggested by Silva et al. (2010b) for J. curcas.

\subsection{Morphological adaptations to drought}

Photosynthesis and growth (biomass production) are the primary processes to be affected by drought (Chaves and Oliveira, 2004). In our study growth reduction was observed under moderate and severe stress. This suggests that even at reduced soil water availability, J. curcas plants are able to grow. Our results agree with the findings of Achten et al. (2010) who have observed that water withhold would arrest growth but maintaining plants at low SWA (40\%) would allow them to continue growing, although at a slower rate than fully irrigated plants. According to our data, the imposed stress period was not long enough to cause any significant differences in biomass at harvest. No differences were also found in biomass partition. However, drought resulted in a reduction of total leaf area in both accessions at the end of the experiment (Table $2, p=0.054$ ). Reduction of canopy size is a water conservation mechanism that allows plants to minimize transpiration area (Boyer, 1970). At the end of our experiments, SLA values ranged between 240 and $260 \mathrm{~cm}^{2} \mathrm{~g}^{-1}$ independently of the treatment or accession (Table 2). This differs from observations by Díaz-López et al. (2012) who found an increase in SLA from 200 to $300 \mathrm{~cm}^{2} \mathrm{~g}^{-1}$ in J. curcas. It is possible that the absence of marked plasticity we observed relates to a constitutively higher SLA in the two tested accessions as compared to those studied by Díaz-López et al. (2012). Moreover, and contrary to Díaz-López et al. (2012), our experiments included a re-watering/recovery period, which could have contributed for the different results.

Reduction in S:R has been described for Jatropha in response to drought (Díaz-López et al., 2012). However, in the way we have imposed water deficit, we did not observe this effect, probably because plant acclimation may have occurred with proportional reductions in plant size or/and no pronounced aerial growth arrest, as can be assumed by the absence of significant biomass differences between control and stress plants at harvest.

\subsection{Leaf gas exchange, Chl fluorescence and Chl content}

Leaf relative water content was kept stable along the trial, and even at maximum stress, which suggests a rapid adjustment of plants to avoid water loss. Similar findings have been described for J. curcas grown under drought (Silva et al., 2010a,b; Díaz-López et al., 2012) and salt stress (Silva et al., 2012). However, Arcoverde et al. (2011) have showed that under severe water stress leaf RWC was moderately reduced. Reduction of stomatal conductance was not related to a decrease in leaf water content (Pompelli et al., 2010; Silva et al., 2010a; Arcoverde et al., 2011), suggesting that stomata are responding to other factors such as hormones (e.g. abscisic acid (ABA) with origin in the drying roots) (Wilkinson and Davies, 2002;

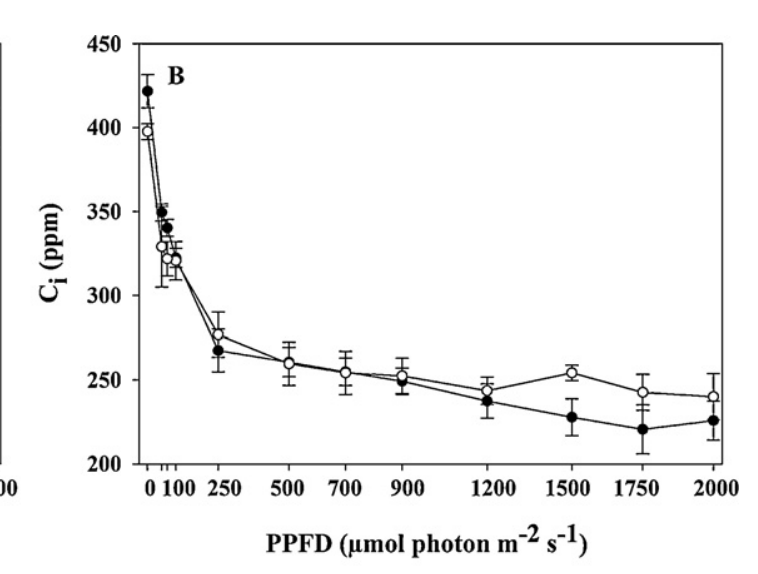

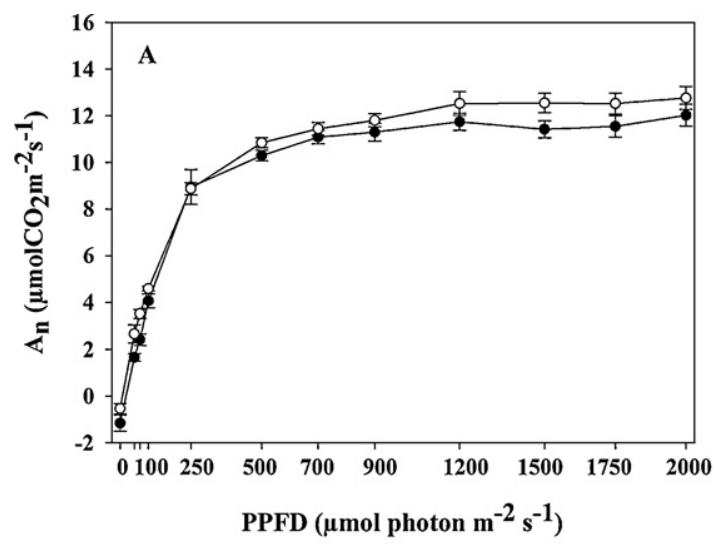

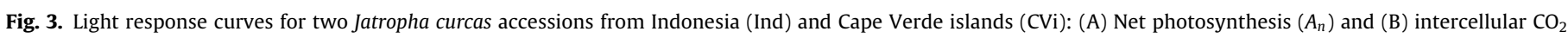
concentration $\left(C_{i}\right)$. Values are means \pm se $(n=5)$. 

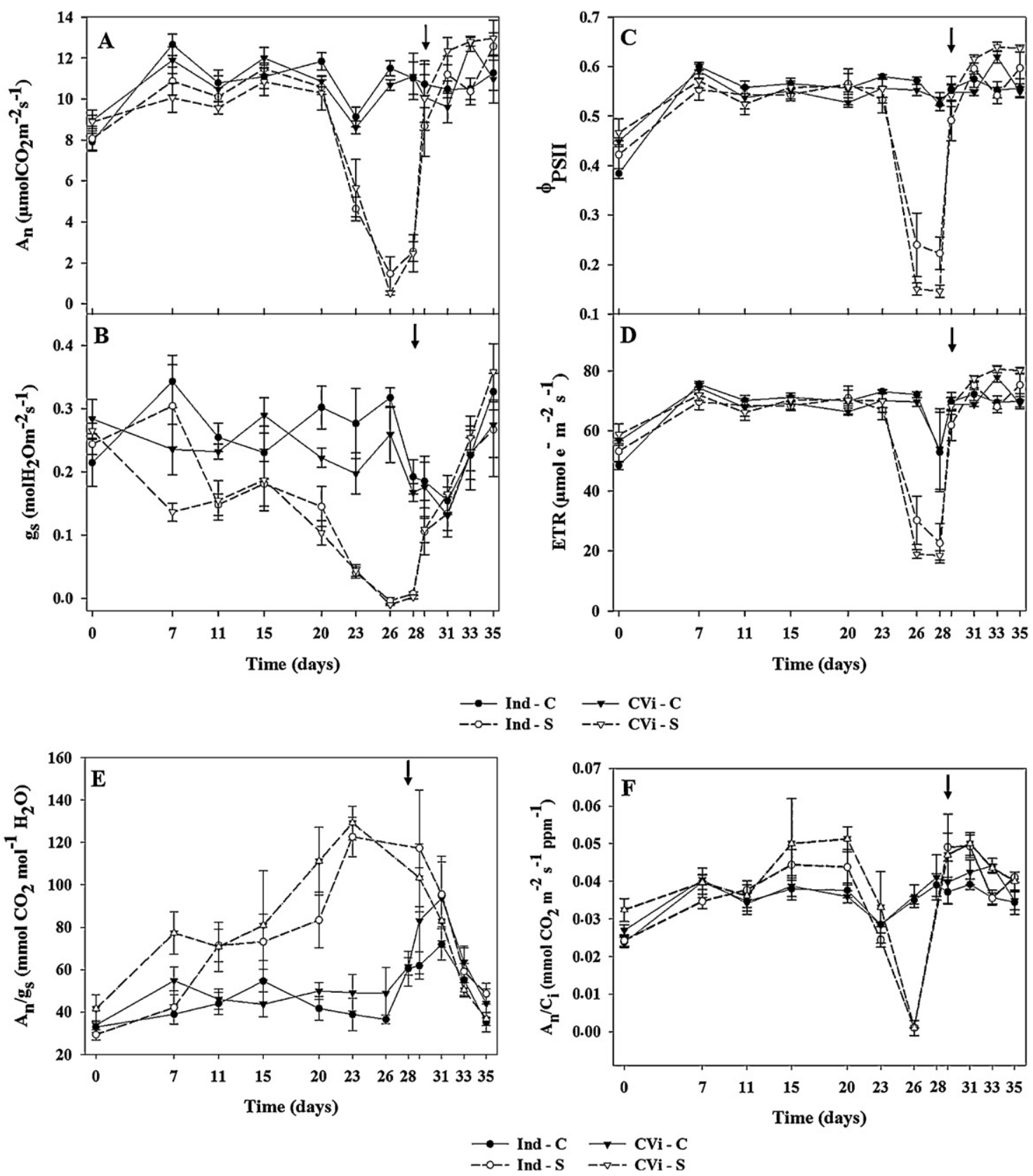

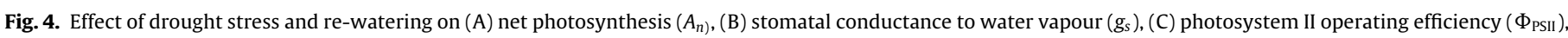

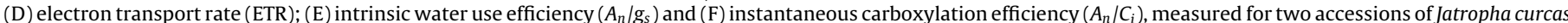

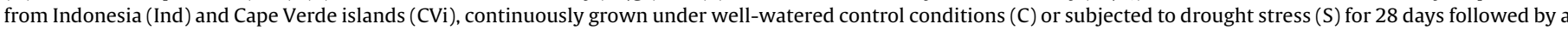

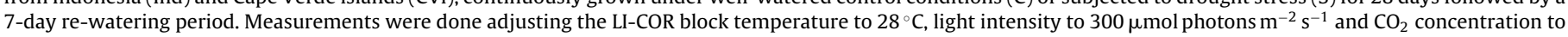

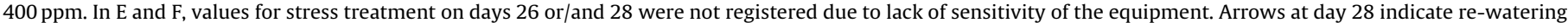
start. Values are means. Bars represent $\pm \operatorname{SE}(n=5)$.

Chaves et al., 2003) to prevent water loss by transpiration. Moreover, there is strong evidence that $g_{s}$ responds to soil water content rather than leaf water content/turgor (Jones, 1985, 1992). However, further studies are needed to test the influence of signalling molecules and their role in this tight stomatal control (e.g. treating leaves of well irrigated plants with ABA). In line with previous findings, our data supports that the main strategy of $J$. curcas to endure drought stress is via a strict stomatal control (Pompelli et al., 2010; Silva et al., 2010a,b; Díaz-López et al., 2012). This also holds true for other Euphorbiaceae species such as Ricinus communis (Sausen and Rosa, 2010), Hevea brasiliensis and Manihot esculenta (El-Sharkawy, 2007).
Interestingly, despite the tight stomatal regulation that we observed under mild and moderate water stress, stomatal limitations to photosynthesis only occurred under severe stress (30-15\% SWA). Although stomatal closure is a fast mechanism that reduces water loss in this species, increasing the resistance of $\mathrm{CO}_{2}$ diffusion in to the mesophyll, carboxylation efficiency is only affected after a reduction of stomatal conductance of approx. 50\% (days 23-26, Fig. 4B and F). This shows the resilience of the photosynthetic apparatus to drought and points to $\mathrm{CO}_{2}$ limitation being the main factor responsible for the decrease of $A_{n}$. This also suggests that this species can be grown under mild to moderate water deficit maintaining high photosynthetic capacity with reduced water loss 


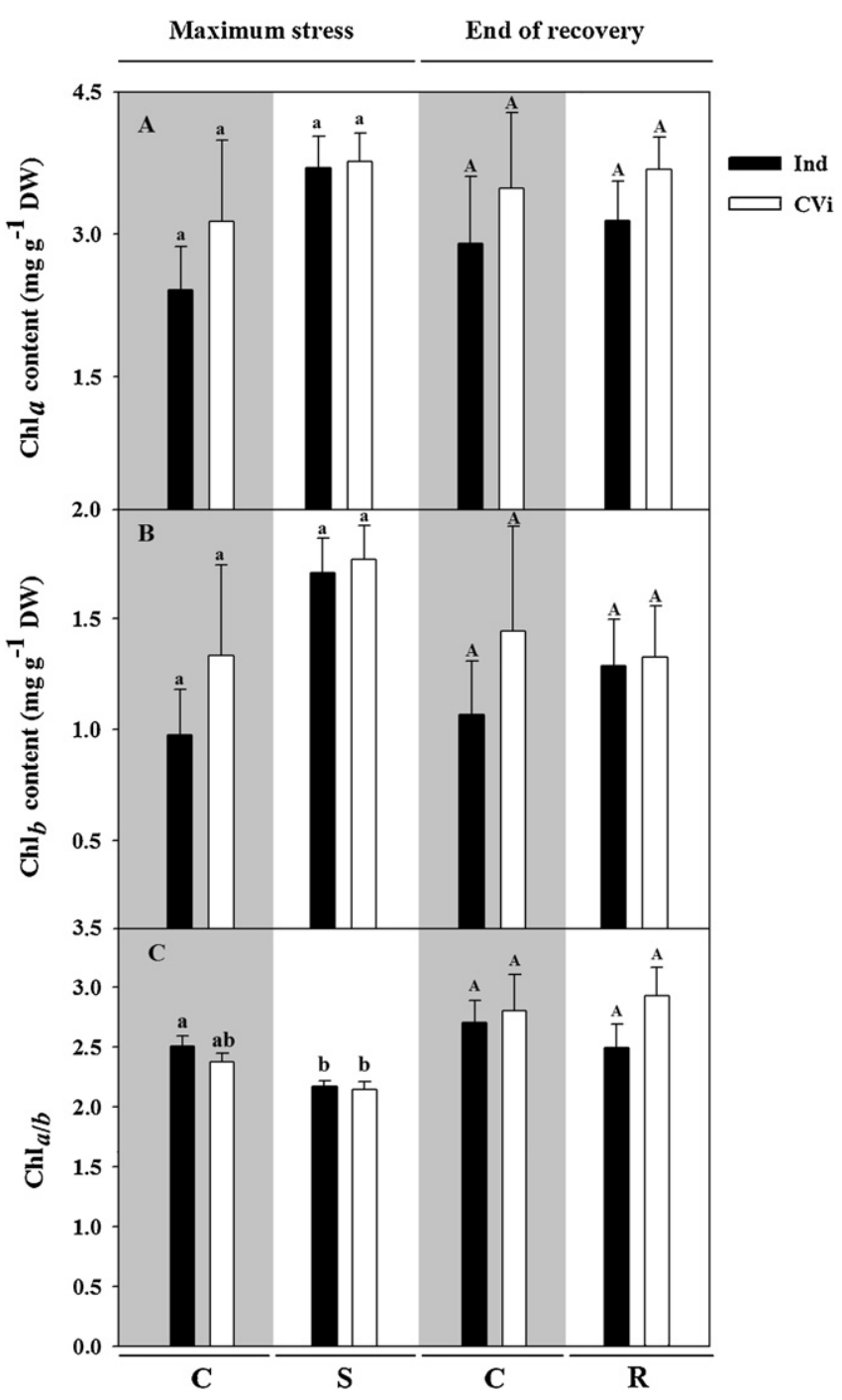

Fig. 5. Effect of drought stress and re-watering on chlorophyll (Chl) content. (A) Chl content, (B) $\mathrm{Chl}_{b}$ content and (C) $\mathrm{Chl}_{a / b}$ ratio measured for leaves of two Jatropha curcas accessions from Indonesia (Ind) and Cape Verde islands (CVi) for plants continuously grown under well-watered control conditions (C) or subjected to drought stress (S) for 28 days, followed by a 7-day re-watering period (R). Sampling points were performed at maximum stress (day 28) and at the end of the 7-day recovery period (day 35$)$. Values are means. Bars represent $\pm \operatorname{SE}(n=5)$. Different letters above the SE-bar indicate significant differences between both treatments according to Tukey's test $(p<0.05)$

and without a significant reduction of biomass, due to an increased WUE $E_{\mathrm{i}}$. The high water use efficiency is a direct consequence of the decrease in $g_{s}$ prior to the decrease in $A_{n}$, which is a typical response observed in other species when subjected to mild drought stress (Medrano et al., 2010) and also for the closely related Manihot sp. (Euphorbiaceae family) (El-Sharkawy, 2007). However, several authors (Silva et al., 2010a,b; Pompelli et al., 2010; Díaz-López et al., 2012) reported a synchronized reduction of stomatal conductance and net assimilation. In our experimental conditions, we observed higher $W_{U E}$ under mild to moderate water deficits. Moreover, WUE $_{\mathrm{i}}$ was higher in stressed plants with SWA values between 60 and $20 \%$ (Fig. 4E), which is contrasting to the results of Díaz-López et al. (2012), who observed that reducing soil water content to $50 \%$ decreased water use efficiency.

$\Phi_{\text {PSII }}$ decrease occurred after the net assimilation decrease, reinforcing that stomatal limitations have primarily limited $A_{n}$ rather than photochemistry. Reduced $\mathrm{CO}_{2}$ supply is expected to negatively affect the Calvin cycle, which in turn would limit PSII efficiency. The sequential declines of $A_{n}$ and $\Phi_{\text {PSII }}$ under drought have been described in the literature (Chaves and Oliveira, 2004), and are thought to be caused by the close linkage between the activity of ETR/ $\Phi_{\text {PSII }}$ and photosynthesis (Genty et al., 1989).

Under severe drought stress leaf chlorophyll contents often decline due to chlorophyll degradation (Martínez-Ferri et al., 2004; Jaleel et al., 2009; Anjum et al., 2011). This has also been reported for J. curcas (Pompelli et al., 2010). However, in the present experimental conditions we found no reduction in $\mathrm{Chl}_{a}$ or $\mathrm{Chl}_{b}$ contents, not even at maximum stress (Fig. 5A and B). In fact, some increase was observed which however was not significant. An increase in $\mathrm{Chl}_{a / b}$ ratio during drought has been reported for several species (e.g. Guerfel et al., 2009; Liu et al., 2011), however, in J. curcas we observed a reduction of the $\mathrm{Chl}_{a / b}$ ratios during drought (Fig. 5C, maximum stress). Pompelli et al. (2010) also found a reduction of the $\mathrm{Chl}_{a / b}$ ratio for $J$. curcas although this was accompanied by a decrease in total Chl content, especially of $\mathrm{Chl}_{a}$. In our experiments, the reduction of $\mathrm{Chl}_{a / b}$ ratio was due to an increase in $\mathrm{Chl}_{b}$ contents.

We observed that after re-watering $\mathrm{Chl}_{a / b}$ was found to increase in stressed plants up to the control values, suggesting that reduction of $\mathrm{Chl}_{a / b}$ ratio is a specific response to drought. It is known that $\mathrm{Chl}_{a / b}$ ratio is inversely related to the antenna size (Tanaka et al., 2001). Although large antennas are particularly described for low light conditions, it might be interesting to investigate their putative correlation with $\mathrm{Chl}_{a / b}$ content in response to drought stress in J. curcas.

\subsection{Recovery following re-watering}

The recovery of photosynthetic rates after water stress depends on the intensity of stress imposition. After a moderate stress it can be fast and complete, but after severe stress recovery of photosynthesis can last from days to weeks and sometimes is never complete (Boyer, 1971; Miyashita et al., 2005; Flexas et al., 2006; Chaves et al., 2009, 2011). In our trial, plants of both accessions needed only one day to recover to normal functioning and reach control levels, despite a severe reduction in leaf gas exchange and photosystem II operating efficiency at maximum stress $\left(A_{n}\right.$ reduction to $77 \%, g_{s}$ to $98 \%$ and $\Phi_{\text {PSII }}$ to $65 \%$ ). Such recovery efficiency suggests that the imposed water stress caused no permanent damage to the leaf photochemical system. It also shows the high resilience of both accessions to drought stress as described for other species (Chaves et al., 2009, 2011).

The absence of marked differences between the two accessions studied could be explained by the low genetic diversity observed in J. curcas outside their Meso-American centre of origin (Sun et al., 2008; Basha and Sujatha, 2007; Ranade et al., 2008; Pamidimarri et al., 2009). Moreover, the fact that in our study the mother-plants from which seeds were harvested were growing side-by-side in Cape Verde must also be accounted for, since at epigenetic level this could have reset the Indonesia seed-derived material to Cape Verde climatic conditions. Such putative re-adjustment could attenuate putative differences in drought stress response between both accessions. Although further studies are needed to test this hypothesis, it is interesting to verify that there is increasing evidence that epigenetics plays a relevant role in J. curcas phenotypic diversity (Popluechai et al., 2009; Yi et al., 2010; Kanchanaketu et al., 2012). The findings of Kanchanaketu et al. (2012) are particularly interesting, since these authors showed, by methylation-sensitive amplified fragment length polymorphism (MS-AFLP), that populations with low genetic diversity have high epigenetic variability and a population of $J$. curcas growing in saline areas has specific DNA methylation patterns.

Field trials with $J$. curcas are still needed to evaluate physiological and agronomical behaviour and assess yield under soil water deficit conditions. This is especially important to compare 
accessions from the centre of origin where a higher genetic diversity is available. These studies are particularly relevant for the ongoing breeding programs of $J$. curcas, designed to achieve improved oil production in drought-prone environments.

\section{Conclusions}

The two accessions of $J$. curcas here compared, originating from Cape Verde islands and Indonesia, showed no marked morphophysiological differences in response to drought stress. Our results show that, under a gradual reduction of soil water availability along a 28 days period followed by one week recovery, plants of both accessions are able to maintain a final biomass similar to plants grown under well irrigated conditions. Net photosynthesis was maintained during water deficit, dropping fast only after $30 \%$ of SWA was reached, due to reduced stomatal conductance. Drought stress did not reduce chlorophyll contents but led to decreased chlorophyll $a / b$. Furthermore, this species has shown to improve its water use efficiency along mild to moderate stress keeping a reasonable growth under soil water conditions up to 30\% of SWA and resisting severe drought with a good recovery capacity after rewatering. Our results support the idea that $J$. curcas is appropriate for cultivation in areas with limited water availability.

\section{Acknowledgments}

The present study was funded by Fundação para a Ciência e a Tecnologia (FCT) (projects PTDC/AGR-GPL/101435/2008 and PEst-OE/EQB/LA0004/2011). JM Costa and T Lourenço were also supported by FCT through grants SFRH/BPD/34429/2006 (JMC) and SFRH/BPD/34943/2007 (TL). The authors would like to acknowledge Maria da Graça Palha (Instituto Nacional de Recursos Biológicos, Oeiras, Portugal) for making available the colour image analysis system, and Jacinta Campo for technical support to these analyses. Prof. Manuela Chaves is also gratefully acknowledged for valuable inputs and critical review of the manuscript. The authors would still like to thank the reviewers for their time and valuable comments.

\section{References}

Achten, W.M.J., Maes, W.H., Reubens, B., Mathijs, E., Singh, V.P., Verchot, L., Muys, B., 2010. Biomass production and allocation in Jatropha curcas L. seedlings under different levels of drought stress. Biomass and Bioenergy 34, 667-676.

Anjum, S.A., Xie, X., Wang, L.C., Saleem, M.F., Man, C., Lei, W., 2011. Morphological, physiological and biochemical responses of plants to drought stress. African Journal of Agricultural Research 6, 2026-2032.

Anyia, A.O., Herzog, H., 2004. Water-use efficiency, leaf area and leaf gas exchange of cowpeas under mid-season drought. European Journal of Agronomy 20, 327-339.

Arcoverde, G.B., Rodrigues, B.M., Pompelli, M.F., Santos, M.G., 2011. Water relations and some aspects of leaf metabolism of Jatropha curcas young plants under two water deficit levels and recovery. Brazilian Journal of Plant Physiology 23, 123-130.

Bacelar, E.A., Moutinho-Pereira, J.M., Gonçalves, B.C., Ferreira, H.F., Correia, C.M., 2007. Changes in growth, gas exchange, xylem hydraulic properties and water use efficiency of three olive cultivars under contrasting water availability regimes. Environmental and Experimental Botany 60, 183-192.

Barrs, H.D., Weatherly, P.E., 1962. A re-examination of relative turgidly for estimating water deficit in leaves. Australian Journal of Biological Sciences 15, 413-428.

Basha, S.D., Sujatha, M., 2007. Inter and intrapopulation variability of Jatropha curcas L. characterized by RAPD and ISSR markers and development of populationspecific SCAR markers. Euphytica 156, 375-386.

Bjökman, O., Demmig, B., 1987. Photon yield of $\mathrm{O}_{2}$ evolution and chlorophyll fluorescence characteristics at $77 \mathrm{~K}$ among vascular plants of diverse origins. Planta $170,489-504$.

Boyer, J.S., 1970. Leaf enlargement and metabolic rates in corn, soybean, and sunflower at various leaf water potentials. Plant Physiology 46, 233-235.

Boyer, J.S., 1971. Recovery of photosynthesis in sunflower after a period of low leaf water potential. Plant Physiology 47, 816-820.

Boyer, J.S., 1982. Plant productivity and environment. Science 218, 443-448.
Centritto, M., Lauteri, M., Monteverdi, M.C., Serraj, R., 2009. Leaf gas exchange, carbon isotope discrimination, and grain yield in contrasting rice genotypes subjected to water deficits during the reproductive stage. Journal of Experimental Botany 60, 2325-2339.

Chaves, M.M., Maroco, J.P., Pereira, J.S., 2003. Understanding plant responses to drought-from genes to the whole plant. Functional Plant Biology 30, 239-264.

Chaves, M.M., Oliveira, M.M., 2004. Mechanisms underlying plant resilience to water deficits: prospects for water-saving agriculture. Journal of Experimental Botany 55, 2365-2384.

Chaves, M.M., Flexas, J., Pinheiro, C., 2009. Photosynthesis under drought and salt stress: regulation mechanisms from whole plant to cell. Annals of Botany 103, $551-560$.

Chaves, M.M., Costa, J.M., Saibo, N.J.M., 2011. Recent advances in photosynthesis under drought and salinity. In: Turkan, I. (Ed.), Plant Responses to Drought and Salinity Stress: Developments in a Post-Genomic Era. Academic Press LtdElsevier Science Ltd, London, pp. 49-104.

Costa, J.M., Ortuño, M.F., Lopes, C.M., Chaves, M.M., 2012. Grapevine varieties exhibiting differences in stomatal response to water deficits. Functional Plant Biology 39, 179-189.

Díaz-López, L., Gimeno, V., Simón, I., Martínez, V., Rodríguez-Ortega, W.M., GarcíaSánchez, F., 2012. Jatropha curcas seedlings show a water conservation strategy under drought conditions based on decreasing leaf growth and stomatal conductance. Agricultural Water Management 105, 48-56.

Divakara, B.N., Upadhyaya, H.D., Wani, S.P., Gowda, C.L.L., 2010. Biology and genetic improvement of Jatropha curcas L.: a review. Applied Energy 87, 732-742.

El-Sharkawy, M.A., 2007. Physiological characteristics of cassava tolerance to prolonged drought in the tropics: implications for breeding cultivars adapted to seasonally dry and semiarid environments. Brazilian Journal of Plant Physiology 19, 257-286.

Fairless, D., 2007. Biofuel: the little shrub that could-maybe. Nature 449, 652-655.

Flexas, J., Bota, J., Loreto, F., Cornic, G., Sharkey, T.D., 2004. Diffusive and metabolic limitations to photosynthesis under drought and salinity in C3 plants. Plant Biology 6, 269-279.

Flexas, J., Bota, J., Galmés, J., Medrano, H., Ribas-Carbó, M., 2006. Keeping a positive carbon balance under adverse conditions: responses of photosynthesis and respiration to water stress. Physiologia Plantarum 127, 343-352.

Flexas, J., Diaz-Espejo, A., Galmés, J., Kaldenhoff, R., Medrano, H., Ribas-Carbo, M., 2007. Rapid variations of mesophyll conductance in response to changes in $\mathrm{CO}_{2}$ concentration around leaves. Plant Cell and Environment 30, 1284-1298.

Genty, B., Briantais, J.M., Baker, N.R., 1989. The relationship between the quantum yield of photosynthetic electron transport and quenching of chlorophyll fluorescence. Biochimica and Biophysica Acta 990, 87-92.

Ginwal, H.S., Rawat, P.S., Srivastava, R.L., 2004. Seed source variation in growth performance and oil yield of Jatropha curcas Linn. in Central India. Silvae Genetica 53, 186-192.

Guerfel, M., Baccouri, O., Boujnah, D., Chaïbi, W., Zarrouk, M., 2009. Impacts of water stress on gas exchange, water relations, chlorophyll content and leaf structure in the two main Tunisian olive (Olea europaea L.) cultivars. Scientia Horticulturae 119, 257-263.

Heller, J., 1996. Physic nut. Jatropha curcas L. In: Promoting the conservation and use of underutilized and neglected crops. 1. Institute of Plant Genetics and Crop Plant Research, Gatersleben/International Plant Genetic Resources Institute, Rome.

Kaushik, N., Kumar, K., Kumar, S., Kaushik, N., Roy, S., 2007. Genetic variability and divergence studies in seed traits and oil content of Jatropha (Jatropha curcas L. accessions). Biomass and Bioenergy 31, 497-502.

Kanchanaketu, T., Sangduen, N., Toojinda, T., Hongtrakul, V., 2012. Genetic diversity analysis of Jatropha curcas L. (Euphorbiaceae) based on methylation-sensitive amplification polymorphism. Genetics and Molecular Research 11, 944-955.

Kumar, R.S., Parthiban, K.T., Rao, M.G., 2008a. Molecular characterization of Jatropha genetic resources through inter-simple sequence repeat (ISSR) markers. Molecular Biology Reports 36, 1951-1956.

Kumar, R.V., Dar, S.H., Yadav, V.P., Tripathi, Y.K., Ahlawat, S.P., 2008b. Genetic variability in Jatropha (Jatropha curcas L.) accessions. Range Management Agroforestry $29,10-12$.

Jaleel, C.A., Manivannan, P., Wahid, A., Farooq, M., Somasundaram, R., Panneerselvam, R., 2009. Drought stress in plants: a review on morphological characteristics and pigments composition. International Journal of Agriculture and Biology 11, 100-105.

Jones, H.G., 1985. Partitioning stomatal and non-stomatal limitations to photosynthesis. Plant, Cell and Environment 8, 95-104.

Jones, H.G., 1992. Plants and Microclimate: A Quantitative Approach to Environmental Plant Physiology, 2nd ed. Cambridge University Press, Cambridge.

Lichtenthaler, H.K., 1987. Chlorophylls and carotenoids: pigments of photosynthetic biomembranes. Methods Enzymology 148, 350-382.

Liu, C., Liu, Y., Guo, K., Fan, D., Li, G., Zheng, Y., Yu, L., Yang, R., 2011. Effect of drought on pigments, osmotic adjustment and antioxidant enzymes in six woody plant species in karst habitats of southwestern China. Environmental and Experimental Botany 71, 174-183.

Maes, W.H., Achten, W.M.J., Reubens, B., Raes, D., Samson, R., Muys, B., 2009. Plantwater relationships and growth strategies of Jatropha curcas L. seedlings under different levels of drought stress. Journal of Arid Environments 73, 877-884.

Martínez-Ferri, E., Manrique, E., Valladares, F., Balaguer, L., 2004. Winter photoinhibition in the field involves different processes in four co-occurring Mediterranean tree species. Tree Physiology 24, 981-990.

Maxwell, K., Johnson, G.N., 2000. Chlorophyll fluorescence: a practical guide. Journal of Experimental Botany 51, 659-668. 
Medrano, H., Flexas, J., Ribas-Carbó, M., Gulías, J., 2010. Measuring water use efficiency in grapevines. In: Delrot, S., Medrano, H., Or, E., Bavaresco, L., Grando, S. (Eds.), Methodologies and Results in Grapevine Research. Springer, London, pp. 124-156.

Miyashita, K., Tanakamaru, S., Maitani, T., Kimura, K., 2005. Recovery responses of photosynthesis, transpiration, and stomatal conductance in kidney bean following drought stress. Environmental and Experimental Botany 53, 205-214.

Pamidimarri, D.V.S., Chattopadhyay, B., Reddy, M.P., 2008a. Genetic divergence and phylogenetic analysis of genus Jatropha based on nuclear ribosomal DNA ITS sequence. Molecular Biology Reports 36, 1929-1935.

Pamidimarri, D.V.S., Singh, S., Mastan, S.G., Patel, J., Reddy, M.P., 2008b. Molecular characterization and identification of markers for toxic and non-toxic varieties of Jatropha curcas L. using RAPD, AFLP and SSR markers. Molecular Biology Reports 36, 1357-1364.

Pamidimarri, D.V.S., Singh, S., Mastan, S.G., Patel, J., Reddy, M.P., 2009. Molecular characterization and identification of markers for toxic and non-toxic varieties of Jatropha curcas L. using RAPD, AFLP and SSR markers. Molecular Biology Reports 36, 1357-1364.

Pompelli, M.F., Barata-Luís, R., Vitorino, H.S., Gonçalves, E.R., Rolim, E.V., Santos, M.G., Almeida-Cortez, J.S., Ferreira, V.M., Lemos, E.E.P., Endres, L., 2010. Photosynthesis, photoprotection and antioxidant activity of purging nut under drought deficit and recovery. Biomass and Bioenergy 34, 1207-1215.

Popluechai, S., Breviario, D., Mulpuri, S., Makkar, H.P.S., Raorane, M., Reddy, A.R., Palchetti, E., Gatehouse, A.M.R., Syers, J.K., O’Donnell, A.G., Kohli, A., 2009. Narrow genetic and apparent phenetic diversity in Jatropha curcas: initial success with generating low phorbol ester interspecific hybrids. Nature Precedings, hdl:10101/npre.2009.2782.1.

Ranade, S.A., Srivastava, A.P., Rana, T.S., Srivastava, J., Tuli, R., 2008. Easy assessment of diversity in Jatropha curcas L. plants using two single-primer amplification reaction (SPAR) methods. Biomass and Bioenergy 32, 533-540.

Rao, G.R., Korwar, G.R., Shanker, A.K., Ramakrishna, Y.S., 2008. Genetic associations, variability and diversity in seed characters, growth, reproductive phenology and yield in Jatropha curcas (L.) accessions. Trees 22, 697-709.
Sausen, T.L., Rosa, L.M.G., 2010. Growth and carbon assimilation limitations in Ricinus communis (Euphorbiaceae) under soil water stress conditions. Acta Botanica Brasilica 24, 648-654.

Singsaas, E.L., Ort, D.R., DeLucia, E.H., 2001. Variation in measured values of photosynthetic quantum yield in ecophysiological studies. Oecologia 128, $15-23$.

Silva, E.N., Ferreira-Silva, S.L., Fontenele A.de.V., Ribeiro, R.V., Viégas, R.A., Silveira, J.A.G., 2010a. Photosynthetic changes and protective mechanisms against oxidative damage subjected to isolated and combined drought and heat stresses in Jatropha curcas plants. Journal of Plant Physiology 167 1157-1164.

Silva, E.N., Ferreira-Silva, S.L., Viégas, R.A., Silveira, J.A.G.da., 2010b. The role of organic and inorganic solutes in the osmotic adjustment of droughtstressed Jatropha curcas plants. Environmental and Experimental Botany 69, 279-285.

Silva, E.N., Vieira, A.S., Ribeiro, R.V., Ponte, F.L.A., Ferreira-Silva, S.L., Silveira, J.A.G., 2012. Contrasting physiological responses of Jatropha curcas plants to single and combined stresses of salinity and heat. Journal of Plant Growth Regulation, http://dx.doi.org/10.1007/s00344-012-9287-3.

Sun, Q.B., Li, L.F., Li, Y., Wu, G.J., Ge, X.J., 2008. SSR and AFLP markers reveal low genetic diversity in the biofuel plant Jatropha curcas in China. Crop Science 48 1865-1871.

Tanaka, R., Koshino, Y., Sawa, S., Ishiguro, S., Okada, K., Tanaka, A., 2001 Overexpression of chlorophyllide a oxygenase (CAO) enlarges the antenna size of photosystem II in Arabidopsis thaliana. Plant Journal 26, 365-373.

Wilkinson, S., Davies, W.J., 2002. ABA-based chemical signalling: the co-ordination of responses to stress in plants. Plant Cell and Environment 25, 195-210.

Yi, C., Zhang, S., Liu, X., Bui, H.T., Hong, Y., 2010. Does epigenetic polymorphism contribute to phenotypic variances in Jatropha curcas L.? BMC Plant Biology 10 , 259. 